\title{
Online Lectures Using Zoom Application for Undergraduate Students During Covid-19 Pandemic Period
}

\author{
Siska Oktaviani \\ Universitas Widya Gama Mahakam Samarinda, Indonesia
}

\begin{abstract}
This research aimed to obtain information about online learning using the Zoom application for the PGSD students of FKIP of Widya Gama Mahakam University of Samarinda during the Covid-19 pandemic. This research used a qualitative descriptive approach. This research subjects were PGSD students who actively participated in online lectures and selected nine sources, namely four students of class 2018 and five students of class 2019. The selection of these sources used a purposive sampling method. Data collection techniques used were observation, interviews via Zoom meeting and WhatsApp, also documentation. The activities in analyzing the data obtained are data reduction, data presentation, drawing-conclusions, and verification. This research used triangulation techniques to test the validity of the data. It can be concluded from the results of this research that lecturers and students as users of the Zoom application need to understand the steps of using the Zoom application to make it easier to take online lectures. The Zoom application is quite effective as a medium for online lectures because it has effectiveness in terms of place, time, services, and facilities, even though there are also obstacles in its use.
\end{abstract}

\section{ABSTRAK}

Penelitian ini bertujuan untuk mendapatkan informasi mengenai pembelajaran daring menggunakan aplikasi Zoom pada mahasiswa PGSD FKIP Universitas Widya Gama Mahakam Samarinda di masa pandemi covid-19. Penelitian ini menggunakan pendekatan deskriptif kualiatif. Subjek penelitian ini adalah mahasiswa PGSD yang aktif mengikuti perkuliahan daring, dan dipilih 9 narasumber yaitu 4 mahasiswa angkatan 2018 dan 5 mahasiswa angkatan 2019. Pemilihan narasumber ini menggunakan metode purposive sampling. Teknik pengumpulan data yang digunakan adalah observasi, wawancara via Zoom Meeting dan Whats App serta dokumentasi. Aktivitas dalam menganalisis data yang diperoleh yaitu reduksi data, penyajian data serta penarikan kesimpulan dan verifikasi. Penelitian ini menggunakan triangulasi teknik untuk menguji keabsahan data. Hasil penelitian ini dapat disimpulkan bahwa dosen dan mahasiswa sebagai pengguna aplikasi Zoom perlu memahami langkah-langkah penggunaan aplikasi Zoom untuk memudahkan saat mengikuti perkuliahan daring. Aplikasi Zoom tergolong cukup efektif sebagai media perkuliahan daring karena memiliki efektifitas dari segi tempat, waktu, layanan dan fasilitas yang dimiliki walaupun juga terdapat kendala dalam penggunaanya.
CONTACT

siska@uwgm.ac.id

KEYWORDS

Online lectures, Zoom

application, Covid-19

Received: 28/02/2021

Revised: 25/03/2021

Accepted: 30/03/2021

Online: $25 / 04 / 2021$

Published: 30/04/2021 Commons Attribution 4.0 International Public Licence (CC-BY 4.0)

\section{INTRODUCTION}

Currently, the world has been facing the global Covid-19 pandemic for a year. In Indonesia, in particular, there have been many preventive measures taken by the government. One of them was through a circular letter from the Ministry of Education and Culture of the Directorate General of Higher Education Number 1 of 2020 concerning the prevention of the causes of coronavirus disease (Covid-19) in universities. The circular appealed to universities to organize distance learning and advised undergraduate students to do learning from home.

Many universities have responded readily to this circular. Based on the explanation by the Directorate General of Higher Education of the Ministry of Education and Culture (CNN Indonesia, 2020) nearly 98\% of universities in Indonesia have conducted online learning, including Widya Gama Mahakam University (UWGM) of Samarinda, which published a circular that consisted of 7 points. One of them was about conducting online lectures to prevent all UWGM of Samarinda academicians from the spread of Covid-19. According to (Sulistiono, 2019) online learning is a learning process in cyberspace using internet-based technology learning 
media. Online learning can be conducted in various type of learning media, such as using Schoology (Sumardani, 2020), 3D Pageflip Website (Bakri, 2016; Sumardani, 2019), and Wordpress (Muliyati, 2019).

The selection of learning media must be considered well to have a positive impact. Educators must understand what principles and factors can affect the learning process using these learning media (Putrawangsa \& Hasanah, 2018). One of the technology-based learning media that can be used is video conferencing.

Virtual lectures via video conferencing applications that are connected to an internet network can replace usual face-to-face lectures. According to (Sandiwarno, 2016) an ideal lecture should interact between lecturers and students even though they are not in the same place. The presence of video conferences will help the lecture process because lecturers continue to interact with students.

One application with virtual face-to-face interaction via video conferencing with a laptop or smartphone is the Zoom application. It is an application created by Eric Yuan in 2011. This application allows users to conduct video conferences, web conferences, to webinars for free with a capacity of 100 participants with a time limit of 40 minutes and no time limit with a paid Zoom account.

The Zoom application has various features that make it easier for lecturers or students to online lectures. Its use is also relatively easy to learn. So that with this application, the lecture process will continue to run according to the government's appeal.

This was supported by previous research which had conducted (Ismawati \& Prasetyo, 2020) that learning carried out through video conferencing was very effective, interactive, and supported distance learning to ease the students for absorbing the material because it was delivered in real-time. In addition, it was also supported by research conducted (Liu \& Ilyas, 2020) regarding online learning based on Zoom Cloud Meetings, the results showed that $12.30 \%$ of students strongly agreed, $46.93 \%$ of students agreed, $25.28 \%$ of students were doubtful, 7. $40 \%$ of students disagreed, and $3.17 \%$ of students strongly disagreed.

One of the faculties that have implemented online lectures is the faculty of teacher training and education (FKIP), to be precise, the primary school teacher education (PGSD) study program. In online lectures conducted by PGSD lecturers and students, the more often used online application is the Zoom application. This research aimed to obtain information about online learning using the Zoom application for PGSD students of FKIP of Widya Gama Mahakam University of Samarinda during the Covid-19 pandemic.

\section{METHODS}

This research used a qualitative descriptive approach. According to (Faisal, 2010) descriptive research does not ask the relationship between variables because this research only describes the variables related to the research problem. This research was conducted at the Widya Gama Mahakam University Campus in Samarinda, located at KH. Wahid Hasyim street No. 28 RT.007, South Sempaja Village, North Samarinda Sub-district, Samarinda City, East Kalimantan Province, in the odd semester of the 2020/2021 academic year starting from October 2020 to January 2021.

The subjects of these researches were PGSD students who were actively participating in online lectures. Then, nine speakers were selected, namely four students of the 2018 batches and five students of the 2019 batches, seven of them were female, and two others were male. The selection of the interviewees used the purposive sampling method. According to (Sugiyono, 2014) purposive sampling is the existence of specific considerations in sampling.

Table 1. The Profile of The Interviewees

\begin{tabular}{|c|c|c|c|}
\hline Initials & Gender & Age & Interview Schedule \\
\hline N1 & Female & 20 years old & $\begin{array}{l}\text { Monday, January 4, 2021, } \\
\text { at } 17.12 \text { UTC+8/ WITA }\end{array}$ \\
\hline $\mathrm{N} 2$ & Female & 20 years old & $\begin{array}{l}\text { Monday, January 4, 2021, } \\
\text { at } 16.04 \text { UTC+8/ WITA }\end{array}$ \\
\hline N3 & Female & 20 years old & $\begin{array}{l}\text { Monday, January 4, 2021, } \\
\text { at } 14.34 \text { UTC+8/ WITA }\end{array}$ \\
\hline N4 & Male & 20 years old & $\begin{array}{l}\text { Wednesday, January 6, } \\
\text { 2021, at } 19.11 \text { UTC+8/ } \\
\text { WITA }\end{array}$ \\
\hline N5 & Male & 19 years old & $\begin{array}{l}\text { Monday, January } 11,2021 \text {, } \\
\text { at } 20.37 \text { UTC+8/ WITA }\end{array}$ \\
\hline N6 & Female & 19 years old & $\begin{array}{l}\text { Tuesday, January 12, 2021, } \\
\text { at } 10.10 \text { UTC+8/ WITA }\end{array}$ \\
\hline
\end{tabular}




$\begin{array}{lll}\text { N7 } & \text { Female } & 19 \text { years old } \\ \text { N8 } & \text { Female } & 19 \text { years old } \\ \text { N9 } & \text { Female } & 19 \text { years old }\end{array}$

Friday, January 8, 2021, at 20.15 UTC+8/ WITA

Tuesday, January 12, 2021, at 13.22 UTC+8/ WITA

Monday, January 11 , 2021, at $19.13 \mathrm{UTC}+8 /$ WITA

Data collection techniques used were observation, interviews via Zoom meeting and WhatsApp, and documentation. Aspects that were asked during the interview were (1) steps to use of Zoom application, (2) the effectiveness of using the Zoom application, and (3) the constraints of using the Zoom application in online lectures.

According to Bogdan (Sugiyono, 2015) data analysis is the process of systematically searching and compiling data obtained from interviews, documentation, and others to be understood and informed to others.

For obtaining data that was in accordance with the framework, three main steps were taken in this research. According to Miles and Huberman (Sugiyono, 2015) qualitative data analysis can be carried out interactively and continues until it is complete and the data is saturated. Activities in analyzing are data reduction, data presentation, and conclusion drawing and verification.

This research used triangulation techniques to test the validity of the data. Wiersma (Sugiyono, 2015) stated that triangulation is qualitative validation that assesses the adequacy of data following the convergence of several data sources or several data collection procedures. Technical triangulation was used to test the data validity related to this research problem. The triangulation was carried out using various techniques to reveal data on the data source (Komariah, 2011)

\section{RESULTS AND DISCUSSIONS}

\section{The steps of the use of Zoom application}

Several online applications were used based on field observations, such as the LMS Portal, WhatsApp, Google Classroom, Google Meet, and Zoom Meeting. The interview results obtained information that online lectures were dominated by using the Zoom application, and the steps for using the Zoom application were considered simple and relatively easy because they could be done via a laptop or smartphone that was owned. According to (Kuntarto, 2017) online learning initially describes the use of computer-based internet technology, but in line with the development of the online learning era, it can be accessed via smartphone.

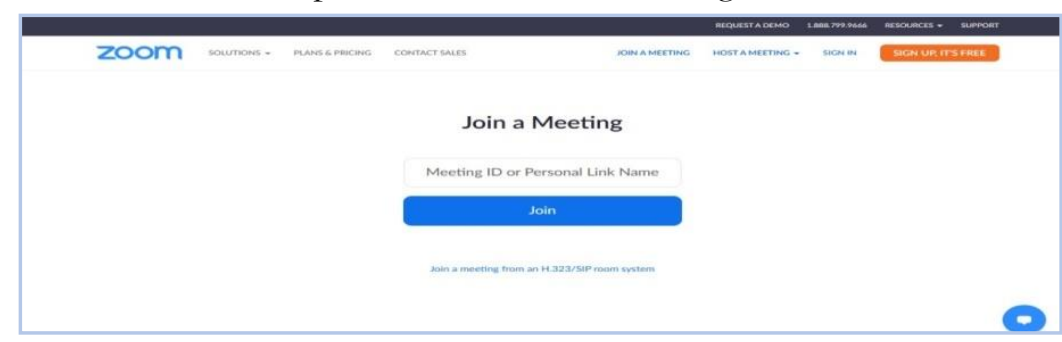

Figure 1. Initial view of the Zoom application

The steps of using Zoom application that were applied during online lectures were as follows: (1) the lecturer directed students to download the Zoom application via their laptop or smartphone; (2) students were given a meeting ID or personal link name to be able to join the meeting; (3) after getting a meeting ID or personal link name, students could join by clicking join; (4) after that, students could take online lectures through the Zoom application. 


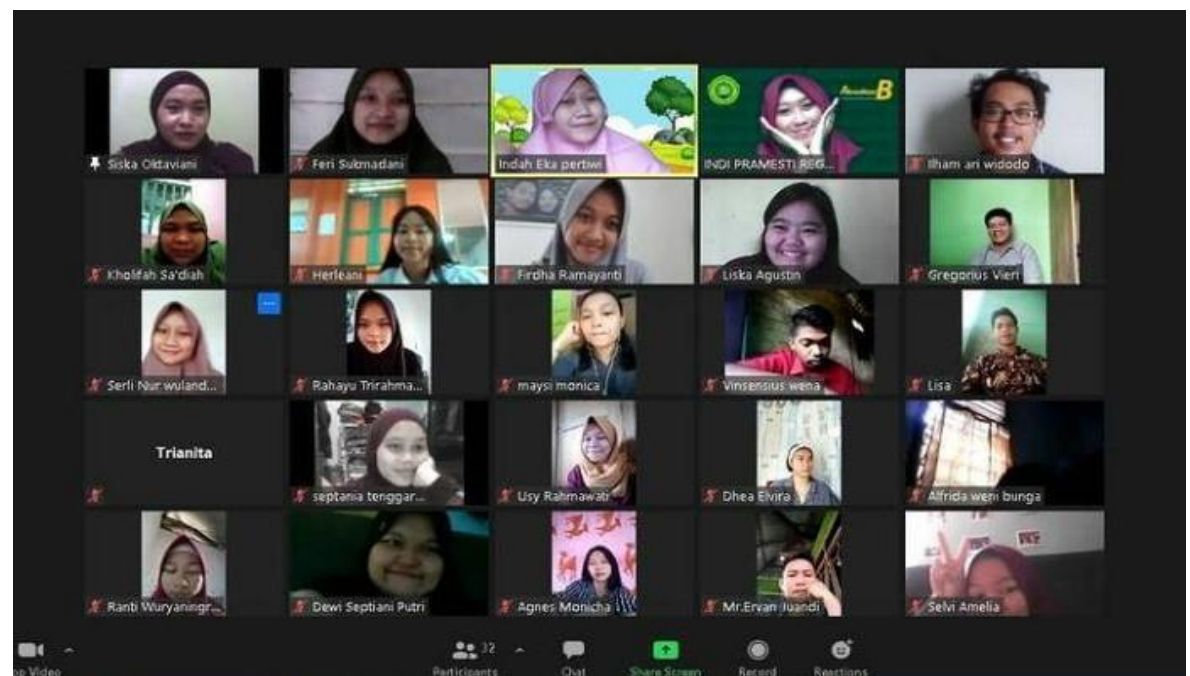

Figure 2. The lecture view using the Zoom application

According to (Hidayatullah, Khouroh, Windhyastiti, Patalo, \& Waris, 2020) lecturers and students as zoom application users felt that the system in the zoom application was very simple and easy to learn. Besides that, the Zoom application was also easy to access, so it did not require special skills to use it.

\section{The effectiveness of the use of Zoom application in online lectures}

The results of observations and interviews with informants obtained information that online lectures with the Zoom application were classified as effective. According to (Rohmawati, 2015) the effectiveness of learning is a standard measure of the interaction between students or between students and educators in the educational process to achieve the goals of learning.

Zoom applications are effective in terms of place and time. Students can do online lectures with the Zoom application at their respective homes without going to campus. By activating the internet network and opening the Zoom application, students can take part in lectures and lecturers. The use of the Zoom application in online lectures also helps lecturers be easier in monitoring students' attendance because, during face-to-face lectures, lecturers often wait for students who are late to attend lectures. After all, the distance from home to campus is relatively far, so it takes lecture hours. Meanwhile, online lectures make students and lecturers do not need to wait too long to start lectures. Online lectures also make students more flexible. According to (Firman \& Rahayu, 2020) students are more comfortable expressing opinions and asking questions during online lectures because lecturers' physical absence makes it easier for them to communicate and express their thoughts.

Furthermore, the Zoom application has effectiveness in terms of services and facilities. Zoom application has a video conferencing feature that can accommodate up to 1000 people without a conference time limit for paid subscribers. However, the Zoom application also has a free version, with 100 people with a conference duration limit of around 40 minutes. According to (Setiani, 2020) the Zoom application was equipped with a feature of a share screen that could present teaching materials liked face-to-face meetings in conventional classrooms, so the material was easily understood by students.

The Zoom application can be facilitated by the annotate feature, which is used to write, move the mouse, stamp, spotlight, eraser, format, etc. This feature is a substitute for the whiteboard in class. The Zoom application is also equipped with a record feature that is used to record video conferences that have been conducted and can be viewed again on a Zoom device or account so that lecturers and students can repeat the recording of lectures that have been taking place. Furthermore, the Zoom application can also facilitate students in group discussions well even though sometimes they are constrained. 


\section{The obstacles of the use of Zoom application during online lectures}

According to (Sihadi, Pangemanan, \& Gamaliel, 2018) obstacles are anything that hinders the process and results. Like other applications, the Zoom application is also inseparable from obstacles when used in online lectures. The dominant obstacles come from the user's respective devices. Based on the results of the interview, there are several obstacles in using the Zoom application, including:

a. Storage Capacity on Mobile

Almost all undergraduate students have cell phones, but not all of them have adequate phones for online lectures. To install the Zoom application, you need enough storage memory or cellphone RAM because it has a large enough megabyte (MB) size. When students install a Zoom application with low RAM, it will automatically fill the cell phone memory and make application access choked up. There are even students who have blank cell phones when accessing the Zoom application, so they cannot take online lectures.

b. Internet Network

An unstable network sometimes constrains online lectures through the Zoom application, so its access is disconnected by itself. This factor is due to the location range of each provider that students use, with different locations where they access the Zoom application to happen. The weather factor also affects the network quality when accessing the Zoom application. If it rains heavily, students may find it difficult to access the Zoom application. This factor can be considered as the most crucial aspect. After all, if lectures are still forced through the Zoom application, not all students can get advantages from the material presented because some of them are still constrained by unsupportive network conditions. To overcome the problems associated with the network, according to (Kelana, Wulandari, \& Wardani, 2021) the lectures through the Zoom application could be recorded by the host at its application, and then recording the lectures in the form of video could be uploaded on the YouTube page so that students subjected to lagging due to network disruption, you could still listen to lecture material.

c. Data Package

Most student finances are obtained from parents. Online lectures with the Zoom application do not rule out more costs, especially for students who don't use Wi-Fi because they have to buy a data package to attend lectures.

d. Use of Zoom Application in Practicum

Lectures are not only carried out by delivering material, but also several activities. One of them is a practicum. The interview results obtained information that the use of the Zoom application in practicum was still not effective because practicum activities took a long time. If the students used the Zoom application, they had to provide much more quota. (Haqien \& Rahman, 2020) added that in the practicum course, students found it difficult because the video quality was not so good, therefore the students had difficulty observing the practicum. The interviewees also added that the practicum's ineffectiveness through the Zoom application was due to the response from students who felt less compact. It was because the network was unstable, which made noise when conveying information was interrupted.

\section{SUGGESTION}

Suggestions for further research were the number of respondents could be larger and wider so that they could find out more details about the effectiveness of using the Zoom application, and focused on research about student learning outcomes, whether it was cognitive, affective, or psychomotor conducted through online lectures with various applications.

\section{CONCLUSIONS}

Based on the results of the research obtained, the researchers concluded that lecturers and students must understand using the Zoom application to make it easier to take online lectures. The Zoom application was quite effective as a medium for online lectures because it had effectiveness in place and time. By simply activating the internet network and open the Zoom application, lecturers and students could conduct lectures. Zoom application has effectiveness in terms of services and facilities as well, because it has such as the video conference feature, share screen, annotate, record and many more features that supported the online lecture process. However, the Zoom application also had several obstacles, including inadequate storage capacity on student cell phones to install Zoom applications, bad internet network due to internet coverage with the distant location of the student's home and unsupportive weather, excessive spending to buy data packages, and the ineffective practicum activities if conducted using Zoom application. 


\section{ACKNOWLEGDEMENTS}

The author would like to thank the Institute of Research and Community Services (LPPM) of the Widya

Gama Mahakam University of Samarinda, who has provided financial assistance for this research activity.

\section{REFERENCES}

Bakri, F., Siahaan, B. Z., \& Permana, A. H. (2016). Rancangan Website Pembelajaran Terintegrasi dengan Modul Digital Fisika Menggunakan 3D PageFlip Professional. Jurnal Penelitian \& Pengembangan Pendidikan Fisika, 2(2), $113-118$.

CNN Indonesia. (2020). 98 Persen Kampus PJJ Daring, Kemdikbud Klaim Mahasiswa Siap. Retrieved from https://www.cnnindonesia.com/nasional/20200903012249-20-542198/98-persen-kampus-pji-daringkemdikbud-klaim-mahasiswa-siap

Faisal, S. (2010). Format-format Penelitian Sosial. Jakarta: Rajawali Pers.

Firman, F., \& Rahayu, S. (2020). Pembelajaran online di tengah pandemi covid-19. Indonesian Journal of Educational Science (IJES), 2(2), 81-89.

Haqien, D., \& Rahman, A. A. (2020). Pemanfaatan Zoom Meeting untuk Proses Pembelajaran pada Masa Pandemi Covid-19. SAP (Susunan Artikel Pendidikan), 5(1).

Hidayatullah, S., Khouroh, U., Windhyastiti, I., Patalo, R. G., \& Waris, A. (2020). Implementasi Model Kesuksesan Sistem Informasi DeLone And McLean Terhadap Sistem Pembelajaran Berbasis Aplikasi Zoom Di Saat Pandemi Covid-19. Jurnal Teknologi Dan Manajemen Informatika, 6(1), 44-52.

Ismawati, D., \& Prasetyo, I. (2020). Efektivitas pembelajaran menggunakan video zoom cloud meeting pada anak usia dini era pandemi covid-19. Jurnal Obsesi: Jurnal Pendidikan Anak Usia Dini, 5(1), 665-675.

Kelana, J. B., Wulandari, M. A., \& Wardani, D. S. (2021). Penggunaan Aplikasi Zoom Meeting di Masa Pandemi Covid-19 Pada Pembelajaran Sains. Jurnal Elementary: Kajian Teori Dan Hasil Penelitian Pendidikan Sekolah Dasar, 4(1), 18-22.

Komariah, A. dan D. S. (2011). Metode Penelitian Kualitatif. Bandung: Alfabeta.

Kuntarto, E. (2017). Keefektifan model pembelajaran daring dalam perkuliahan bahasa Indonesia di perguruan tinggi. Indonesian Language Education and Literature, 3(1), 99-110.

Liu, A. N. A. M., \& Ilyas, I. (2020). Pengaruh Pembelajaran Online Berbasis Zoom Cloud Meeting Terhadap Hasil Belajar Mahasiswa Fisika Universitas Flores. Jurnal Pendidikan Fisika Dan Keilmuan (JPFK), 6(1), 34-38.

Muliyati, D., Herga Marizka, \& Bakri, F. (2019). E-Learning Using Wordpress on Physics Materials with The 5E Learning Cycle Strategy. Jurnal Penelitian \& Pengembangan Pendidikan Fisika, 5(2), 101 - 112.

Putrawangsa, S., \& Hasanah, U. (2018). Integrasi teknologi digital dalam pembelajaran di era industri 4.0. Jurnal Tatsqif, 16(1), 42-54.

Rohmawati, A. (2015). Efektivitas pembelajaran. Jurnal Pendidikan Usia Dini, 9(1), 15-32.

Sandiwarno, S. (2016). Perancangan Model E-Learning Berbasis Collaborative Video Conference Learning Guna Mendapatkan Hasil Pembelajaran yang Efektif dan Efisien. Jurnal Ilmiah FIFO, 8(2), 191-200.

Setiani, A. (2020). Efektivitas Proses Belajar Aplikasi Zoom di Masa Pandemi dan Setelah Pandemi Covid-19. In Prosiding Seminar Nasional Pascasarjana (PROSNAMPAS) (Vol. 3, pp. 523-530).

Sihadi, I. P., Pangemanan, S. S., \& Gamaliel, H. (2018). Identifikasi Kendala dalam Proses Produksi dan Dampaknya Terhadap Biaya Produksi pada UD. Risky. Going Concern: Jurnal Riset Akuntansi, 13(04).

Sugiyono. (2014). Memahami Penelitian Kualitatif. Bandung: Alfabeta.

Sugiyono. (2015). Metode Penelitian Pendidikan Pendekatan Kuantitatif, Kualitatif dan R\&D. Bandung: Alfabeta.

Sulistiono, M. (2019). Implementasi Hybrid learning menggunakan aplikasi Edmodo pada matakuliah metode penelitian kualitatif. Elementeris: Jurnal Ilmiah Pendidikan Dasar Islam, 1(1), 57-67.

Sumardani, D., Arifin F., Hendrawan, R. (2019). Designing 3d Pageflip Professional On Core Stability And Radioactivity For High School Student. Proceeding Asean Youth Conference, Kuala Lumpur, Malaysia, 2019.

Sumardani, D., Putri, A., \& Sumardani, N. I. (2020). E-Learning Utilizing Schoology: Teaching Theory of Relativity Using Online. Risenologi, 5(1), 48-55. 